TTGGTTTG) exist in the glucocorticoidresponsive region of MMTV between the two hormone-binding sites.

The obvious question is whether MMTV contains an enhancer whose only difference from those of other viral enhancers is that it requires a steroid hormone for activation or, alternatively, do all classes of steroid hormone modulate gene transcription by activating enhancer sequences? Moreover, in MMTV, although most effort has been devoted to characterizing the glucocorticoid-responsive region associated with the promoter, it is clear that specific hormone binding occurs elsewhere in the viral genome. In view of the location of an enhancer downstream of the immunoglobulin promoter ${ }^{2,12-16}$, it will be intriguing to discover whether MMTV contains additional enhancers which are activated by glucocorticoid. If enhancer elements play a part in the mechanism whereby all steroid hormones act, then specificity of response to different hormones must reside in the DNA sequence of the enhancer. However, there are genes such as the egg-white and $\alpha 2 \mu$ globulin genes whose expression is stimulated by more than one hormone and yet in the case of the lysozyme gene the same region of DNA appears to confer sensitivity to both progesterone and glucocorticoid. Presumably, hormones must bind to distinct sequences in this region, resulting in activation of one and the same enhancer sequence.

Malcolm Parker is in the Department of Molecular Endocrinology, Imperial Cancer Research Fund, Lincoln's Inn Fields, London $W C 2 A 3 P X$.

Khoury, G. \& Gruss, P. Cell 33, 313 (1983)

2. Boss, MA Nature 303, 281 (1983).

3. Scheideret, C., Geisse, S., Westphal, H.M. \& Beato, M. Nature 304, 749 (1983).

4. Hynes, N. et al. Proc. natn. Acad. Sci. U.S.A. 80 3637 (1983).

5. Compton, J.G., Schrader, W.T. \& O'Malley, B.W. J. Steroid Biochem, (in the press).

6. Mulvihill, E.R., LePennec, J.P. \& Chambon, P. Cell 24, 621 (1982)

7. Compton, J.G., Schrader, W.T. \& O'Malley, B.W. Proc. natn. Acad. Sci. U.S.A. 80, 6 (1983).

8. Dean, D.C., Knoll, B.J., Riser, M.E. \& O'Malley, B.W J. Steroid Biochem. (in the press)

9. Renkawitz, R. et al. Cell 31, 167 (1982).

10. Renkawitz, R., Danesch, U., Matthias, P. \& Schütz, G. J. Steroid Biochem. (in the press).

11. Chandler, V.L., Maler, B.A. \& Yamamoto, K.R. Cell 33, 489 (1983)

12. Gilles, S.D., Morrison, S.L., Oi, V.T. \& Tonegawa, S. Cell 33, 717 (1983)

13. Banerji, J., Olson, L. \& Schaffner, W. Cell 33, 729 (1983).

14. Queen, C. \& Baltimore, D. Cell 33, 741 (1983).

15. Emorine, L., Kuehl, M., Weir, L., Leder, P. \& Max, E.E. Nature 304, 447 (1983).

16. Neuberger, M.s. EMBO J. 2, 1373 (1983).

\title{
Ecology
}

\section{Evolution of linear habitats in Britain}

\section{from Peter D. Moore}

IF there is one feature that distinguishes a human hand in the construction of a landscape it is linearity. Linearity is generally displeasing to those who, with blinkered optimism, still like to think of nature as being free from human influence, but the impact of linear features upon the natural world is not always harmful from the point of view of biological diversity ${ }^{1}$.

There are cases, of course, where the construction of such features as a road or railway across a habitat can be regarded as harmful because it causes fragmentation and so, by creating barriers to migration, reduces the effective area of that habitat and hence its biological diversity. Usher ${ }^{2}$, for example, claims that the species-area relationship for plants in native reserves in Yorkshire, England, approximates to that expected from classic island biogeographical theory in which $S=c A^{z}$, where $S=$ species number, $A=$ habitat area and $c$ and $z$ are constants. Reduction in habitat size is thus linked with decreased diversity.

On the other hand, many other considerations must be taken into account in the development of conservation policy, for example, the need for fire breaks in firevulnerable habitats where catastrophe could otherwise destroy large areas, and the existence in nature of concentrations of species in certain peculiar and often small sites. Several commentators have concluded that a number of small sites for conservation can be more valuable than a few large ones ${ }^{3,4}$.

The linear features themselves may also provide a habitat for plants and animals. Road verges ${ }^{5}$ and railway lines are both recognized as important semi-natural linear habitats. In a recent survey of disused lines in Norfolk, Leaney ${ }^{6}$ found over 500 species of vascular plants in a series of samples totalling 73.5 miles in length, including many rarities for particular parts of the country. Hedges have perhaps received more attention than any other linear habitat $^{7}$ and are generally looked upon favourably by conservationists.

In eastern Britain, particularly in the fenlands and the Broadland regions, linear systems of dykes or drainage ditches are more frequently used for marking field boundaries and containing stock than are hedges, and these too may represent an important reservoir of aquatic wildlife. The dykes usually have a gradual gradient and hence slowly moving waters ${ }^{8}$, which provides a generally high water table. Often pumps are required to control water movement and, obviously, a lush growth of aquatic plants is frowned upon if they are to provide an efficient means of land drainage.

Driscoll ${ }^{9}$, in surveying these waterways, has concluded that dykes draining arable land are less rich biologically than those from pasture areas, and the intensity of pastoral management is also related inversely to wildlife potential. In an 8-year survey he documented a decline in aquatic species number of about 17 per cent in areas where a shift from pastoral to arable land had occurred.

Driscoll's work also reveals an overall loss of dyke habitat in recent years, just as has happened with hedges. A detailed survey ${ }^{10}$ of dyke patterns in one of his survey sites which has been converted to arable farming showed that, between 1973 and $1981,33.5$ per cent of the dykes had been filled in, and he fears that if this continues, it will have a harmful effect on some of our typically dyke flora, such as the water soldier Stratiotes aloides.

Driscoll's maps of past and present dyke patterns also reveal a simplification and fragmentation of the once complex network of waterways, and this leads to the question of whether, and if so how, their loss affects plant and animal dispersal. Are these linear habitats important migration routes for aquatic organisms between larger water bodies?

Similar questions have been asked about our other linear habitats. Railways certainly have provided a means of transport and dispersal for many plant species, the classic example being the Oxford ragwort (Senecio squalidus) in the nineteenth century ${ }^{11}$. The winter-salted road system of Britain is currently providing migration routes for halophytic plants ${ }^{12}$. Hedges, on the other hand, do not seem to act as channels for the movement of woodland plants from one relict fragment of forest to another ${ }^{13}$.

The dykes have not yet been examined from this point of view. But if they do prove to have been valuable arteries of dispersal for both plants and animals, it makes their loss doubly regrettable.

Peter D. Moore is a Senior Lecturer in the Department of Plant Sciences, University of London King's College, 68 Half Moon Lane, London SE24 9JF.

1. Yapp, W.B. Biol. Conserv. 5, 45 (1973).

2. Usher, M.B.J. appl. Ecol. 16, 213 (1979).

3. Gilpin, M.E. \& Diamond, J.M. Nature 285, 567 (1980).

4. Higgs, A.J. \& Usher, M.B. Nature 285, 567 (1980).

5. Way, J.M. (ed.) Road Verges: their Function and Mangement (Nature Conservancy, London, 1969).

6. Leaney, R. Trans. Norf. Norwich nat. Soc. 26, 112 (1983).

7. Pollard, E., Hooper, M.D. \& Moore, N.W. Hedges (Collins, London, 1974).

8. Haslam, S.M. River Plants (Cambridge University Press, 1978).

9. Driscoll, R.J. Watsonia 14, 276 (1983)

10. Driscoll, R.J. Trans. Norf. Norwich nat. Soc. 26, 170 (1983).

11. Kent, D.H. Proc, bot, Soc, Br, Is, 5, 210 (1964)

11. Kent, D.H. Proc. bot. Soc. Br. Is. 5,
12. Moore, P.D. Nature 297, 537 (1982).

13. Helliwell, D. R. Biol. Conserv. 7, 61 (1975) 